in order to test her wireless compasses. A wireless message during the evening reported that all was well and nothing further was heard until a German tanker, the Phabus, reported by wireless that the Akron had 'crashed' at sea and that four of the crew had been picked up, one of whom died later. One of the survivors is Lieut.-Comdr. H. Wiley, the secondin-command, who has recovered sufficiently to make a report on the disaster. The airship sighted a thunderstorm at 8.45 p.m. ; later, the ship at 1,600 ft. appeared to be surrounded by lightning and about midnight she began to descend rapidly. Ballast was thrown out and she regained altitude, only to descend again a few minutes later. The rudder control was carried away as the airship crashed and it seems that the main part of the ship sunk almost immediately. The Akron was the largest airship in the world, her gasbags were filled with helium, and, at the time of the disaster, there were seventy-seven officers and men aboard, including Rear-Admiral William Moffett, chief of the U.S. Naval Bureau of Aeronautics. Rescue work was hampered by the weather, and a 'blimp' returning from a search for survivors was blown into the sea on attempting to land, one of the crew being drowned and the commander dying shortly afterwards. Yet another airship accident has been reported, this time from France, where the semi-rigid naval dirigible E9, crashed near Guerande on April 4, two of the crew of twelve being injured.

\section{Science at the Ideal Home Exhibition}

THE Daily Mail Ideal Home exhibition at Olympia which was opened by Mrs. Stanley Baldwin on March 29 and will remain open until April 29, is, as usual, a remarkable tribute to the influence science now exerts on the equipment of up-to-date houses. Thanks to the use of gas and electricity, the investigations of the chemist, physicist and metallurgist, the duties of every housewife are steadily being lightened and the comfort and con. venience of everyone increased. The gradual improvement in the quality of food and in its preparation, and in all connected with lighting, heating and ventilation is indeed remarkable. New metals, new materials and new designs, and the application of scientific methods are seen on every hand. The exhibition occupies the Grand Hall, the National Hall and the Empire Hall, and in the first of these is an admirable and beautiful scheme of decoration which includes, as its outstanding feature, a portion of an immense rainbow composed of no less than $700 \mathrm{ft}$. of neon tubes, fitted up by Messrs. Venreco, Ltd.

Wrтнобт attempting to refer to the many exhibits which owe so much to scientific research, attention may be directed to the interesting series of "Rooms of the Scientists" in the gallery of the Empire Hall, where "for the first time in history, are gathered together a collection of exhibits more romantic than any story, more sensational in their results than the wildest fiction". There are nine of these rooms showing respectively Archimedes in his villa at Syracuse; Roger Bacon in prison; Newton in his study at Cambridge making his experiment on light; a part of the surgical ward at the Glasgow Royal Infirmary where Lister did his important work during 1861-69; the tent of Sir Ronald Ross in which he made his observations on the relat:on of the mosquito to malaria ; Darwin's study at Down House in which he wrote "The Origin of Species"; a replica of Prof. Piccard's sphere in which he made his record ascent into the air; Faraday's laboratory at the Royal Institution; and lastly, the wireless cabin of the Marchese Marconi on his yacht Elettra. The tableaux are admirably arranged and the eminent men of science are represented by members of the theatrical profession, that of Newton, for example, being played by Mr. Rodney Barrie. The whole exhibit has been staged by Prof. A. M. Low for Armchair Science, with the assistance of many scientific bodies and individuals, including the British Museum, the Science Museum and the Royal Institution.

\section{Bequests for Geological Research}

Mr. Bernard Hobson, of Sheffield, who died on December 3, left estate of the net value of $£ 142,125$. He bequeathed $£ 1,000$ to the Yorkshire Geological Society, Leeds ; $£ 1,000$ to the Geological Society of London, to be called the "Bernard Hobson Fund", the annual income of which is to be used in buying British, Colonial and foreign geological maps, to be placed on linen conveniently folded for the pocket for use of the members of the Society; and $£ 1,000$ to the British Association for the Advancement of Science, to be called the "Bernard Hobson Fund", the annual income of which is to be devoted to promoting definite geological research. After making

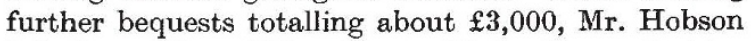
left the residue of his estate to his brother and sister for life, with remainder to the University of Sheffield. Mr. Hobson had been a member of the Council of the University for some years. Ho belonged to a family which had taken a special interest in it. His father, Mr. John Hobson, was a member of the Council of Firth College, from which the University sprang. His brother, the late Sir Albert Hobson, as Master Cutler in 1903, took a leading part in the movement for the establishment of the University, and served successively as Treasurer of the University and ProChancellor. Sir Albert, who died in 1923, also left the residue of his estate to the University.

\section{Research Grant for the Cancer Hospital (Free), London}

ReCentuy the investigations on the chemical aspects of the cancer problem which are in progress at the Research Institute of The Cancer Hospital (Free), Fulham Road, London, have received recognition and financial assistance from two sources. The trustees of the Halley Stewart Trust have made a grant for a period of three years to support a wholetime worker who will undertake biochemical investigations into the metabolism of cancerous growths. Dr. C. A. Mawson of the Victoria University of Manchester has been appointed to carry out this work.

(Continued on p. 509) 